\title{
Redox-Switching of Nonlinear Optical Behavior in Langmuir-Blodgett Thin Films Containing a Ruthenium(II) Ammine Complex
}

Leïla Boubekeur-Lecaque, Benjamin J. Coe, Koen Clays, Stijn Foerier, Thierry Verbiest, and Inge Asselberghs

\section{Supporting Information}

\section{Complete Reference}

(c) Sporer, C.; Ratera, I.; Ruiz-Molina, D.; Zhao, Y.-X.; Vidal-Gancedo, J.; Wurst, K.; Jaitner, P.; Clays, K.; Persoons, A.; Rovira, C.; Veciana, J. Angew. Chem., Int. Ed. 2004, 43, 5266-5268.

\section{Experimental Details}

Materials and Procedures. All reactions were performed under an Ar atmosphere and in Ar-purged solvents. The compounds $\left[2,4-\mathrm{DNPhQ}^{+}\right] \mathrm{Cl} \cdot 0.5 \mathrm{EtOH} \bullet 0.25 \mathrm{H}_{2} \mathrm{O}^{1}$ and $\left[\mathrm{Ru}^{\mathrm{II}}\left(\mathrm{NH}_{3}\right)_{5}\left(\mathrm{H}_{2} \mathrm{O}\right)\right]\left[\mathrm{PF}_{6}\right]_{2}{ }^{2}$ were synthesized by previously published methods. All other reagents were obtained commercially and used as supplied. Products were dried overnight in a vacuum desiccator $\left(\mathrm{CaSO}_{4}\right)$ prior to characterization.

Physical Measurements. ${ }^{1} \mathrm{H}$ NMR spectra were recorded on a Bruker 500 spectrometer and all shifts are referenced to TMS. The fine splitting of pyridyl or phenyl ring patterns is ignored and the signals are reported as simple doublets, with $J$ values referring to the two most intense peaks. Elemental analyses were performed by the Microanalytical Laboratory, University of Manchester and UV-visible spectra were obtained by using a Shimadzu UV-2401 PC spectrophotometer. Cyclic voltammetric measurements were carried out by using an EG\&G PAR model 283 potentiostat/galvanostat. A single-compartment cell was used with a $\mathrm{Ag}-\mathrm{AgCl}$ reference electrode separated by a salt bridge from the glassy carbon disc working electrode and platinum-wire auxiliary electrode. Anhydrous acetonitrile (HPLC grade, distilled under argon from $\mathrm{CaH}_{2}$ ) was used as the solvent and tetra- $n$-butyl ammonium hexafluorophosphate, twice recrystallized from ethanol and dried in vacuo, was used as supporting electrolyte. Solutions containing ca. $10^{-3} \mathrm{M}$ analyte $(0.1 \mathrm{M}$ electrolyte $)$ 
were deaerated by purging with $\mathrm{N}_{2}$. All $E_{1 / 2}$ values were calculated from $\left(E_{\mathrm{pa}}+E_{\mathrm{pc}}\right) / 2$ at a scan rate of $200 \mathrm{mV} \mathrm{s}^{-1}$.

Synthesis of $N$-(4-Hexadecylphenyl)-4,4' -bipyridinium Hexafluorophosphate, $\left[\mathbf{C}_{\mathbf{1 6}}-\mathbf{P h Q}^{+}\right] \mathbf{P F}_{\mathbf{6}}$. A solution of $\left[2,4-\mathrm{DNPhQ}^{+}\right] \mathrm{Cl} \cdot 0.5 \mathrm{EtOH} \cdot 0.25 \mathrm{H}_{2} \mathrm{O}(550 \mathrm{mg}, 1.42 \mathrm{mmol})$ and 4-( $n$-hexadecyl)aniline $(730 \mathrm{mg}, 2.45 \mathrm{mmol})$ in ethanol $(22 \mathrm{~mL})$ was heated under reflux for $24 \mathrm{~h}$. After cooling to room temperature, the precipitate was filtered off, washed thoroughly with diethyl ether and dried. The cream colored solid was dissolved in methanol and poured into saturated aqueous $\mathrm{NH}_{4} \mathrm{PF}_{6}$. The resulting solid precipitate was filtered off, washed with water and dried: $850 \mathrm{mg}, 99 \% ; \delta_{\mathrm{H}}\left(\mathrm{CD}_{3} \mathrm{COCD}_{3}\right) 9.51(2 \mathrm{H}, \mathrm{d}, J=6.6 \mathrm{~Hz}$, $\left.\mathrm{C}_{5} \mathrm{H}_{4} \mathrm{~N}\right), 8.91\left(2 \mathrm{H}, \mathrm{d}, J=5.6 \mathrm{~Hz}, \mathrm{C}_{5} \mathrm{H}_{4} \mathrm{~N}\right), 8.84\left(2 \mathrm{H}, \mathrm{d}, J=6.6 \mathrm{~Hz}, \mathrm{C}_{5} \mathrm{H}_{4} \mathrm{~N}\right), 8.08(2 \mathrm{H}, \mathrm{d}, J=$ $\left.5.6 \mathrm{~Hz}, \mathrm{C}_{5} \mathrm{H}_{4} \mathrm{~N}\right), 7.92\left(2 \mathrm{H}, \mathrm{d}, J=8.3 \mathrm{~Hz}, \mathrm{C}_{6} \mathrm{H}_{4}\right), 7.65\left(2 \mathrm{H}, \mathrm{d}, J=8.3 \mathrm{~Hz}, \mathrm{C}_{6} \mathrm{H}_{4}\right), 2.81(2 \mathrm{H}, \mathrm{t}$, $\left.J=7.8 \mathrm{~Hz}, \mathrm{CH}_{2}-\mathrm{Ph}\right), 1.73-1.60\left(2 \mathrm{H}, \mathrm{m}, \mathrm{CH}_{2}\right), 1.48-1.24\left(26 \mathrm{H}, \mathrm{m}, \mathrm{C}_{13} \mathrm{H}_{26}\right), 0.87(3 \mathrm{H}, \mathrm{t}, J=$ $6.9 \mathrm{~Hz}, \mathrm{Me})$. Anal. Calcd (\%) for $\mathrm{C}_{32} \mathrm{H}_{45} \mathrm{~F}_{6} \mathrm{~N}_{2} \mathrm{P}: \mathrm{C}, 63.77 ; \mathrm{H}, 7.53 ; \mathrm{N}, 4.65$. Found: $\mathrm{C}$, 63.33; H, 7.46; N, 4.38.

Synthesis of $\left[\mathrm{Ru}^{\mathrm{II}}\left(\mathrm{NH}_{3}\right)_{5}\left(\mathrm{C}_{16}-\mathrm{PhQ}^{+}\right)\right]\left(\mathrm{PF}_{6}\right)_{3} \quad$ (1). $\quad A \quad$ solution of $\left[\mathrm{Ru}^{\mathrm{II}}\left(\mathrm{NH}_{3}\right)_{5}\left(\mathrm{H}_{2} \mathrm{O}\right)\right]\left(\mathrm{PF}_{6}\right)_{2}(100 \mathrm{mg}, 0.202 \mathrm{mmol})$ and $\left[\mathrm{C}_{16}-\mathrm{PhQ}^{+}\right] \mathrm{PF}_{6}(72 \mathrm{mg}, 0.119 \mathrm{mmol})$ in acetone $(10 \mathrm{~mL})$ was stirred at room temperature in the dark for $12 \mathrm{~h}$. The resulting dark blue solution was added to saturated aqueous $\mathrm{NH}_{4} \mathrm{PF}_{6}$ and the resulting purple solid was filtered off, washed thoroughly with water and dried: $124 \mathrm{mg}, 96 \% ; \delta_{\mathrm{H}}\left(\mathrm{CD}_{3} \mathrm{COCD}_{3}\right) 9.34(2 \mathrm{H}, \mathrm{d}, J$ $\left.=7.0 \mathrm{~Hz}, \mathrm{C}_{5} \mathrm{H}_{4} \mathrm{~N}\right), 9.21\left(2 \mathrm{H}, \mathrm{d}, J=6.8 \mathrm{~Hz}, \mathrm{C}_{5} \mathrm{H}_{4} \mathrm{~N}\right), 8.85\left(2 \mathrm{H}, \mathrm{d}, J=7.0 \mathrm{~Hz}, \mathrm{C}_{5} \mathrm{H}_{4} \mathrm{~N}\right), 7.96$ $\left(2 \mathrm{H}, \mathrm{d}, J=6.8 \mathrm{~Hz}, \mathrm{C}_{5} \mathrm{H}_{4} \mathrm{~N}\right), 7.87\left(2 \mathrm{H}, \mathrm{d}, J=8.3 \mathrm{~Hz}, \mathrm{C}_{6} \mathrm{H}_{4}\right), 7.62\left(2 \mathrm{H}, \mathrm{d}, J=8.3 \mathrm{~Hz}, \mathrm{C}_{6} \mathrm{H}_{4}\right)$, $3.63\left(3 \mathrm{H}, \mathrm{s}, \mathrm{NH}_{3}\right), 2.79\left(2 \mathrm{H}, \mathrm{t}, J=7.7 \mathrm{~Hz}, \mathrm{CH}_{2}-\mathrm{Ph}\right), 2.72\left(12 \mathrm{H}, \mathrm{s}, 4 \mathrm{NH}_{3}\right), 1.74-1.67(2 \mathrm{H}$, $\left.\mathrm{m}, \mathrm{CH}_{2}\right), 1.43-1.22\left(26 \mathrm{H}, \mathrm{m}, \mathrm{C}_{13} \mathrm{H}_{26}\right), 0.88(3 \mathrm{H}, \mathrm{t}, J=7.0 \mathrm{~Hz}, \mathrm{Me})$. Anal. Calcd (\%) for $\mathrm{C}_{32} \mathrm{H}_{60} \mathrm{~F}_{18} \mathrm{~N}_{7} \mathrm{P}_{3} \mathrm{Ru} \cdot \mathrm{C}_{3} \mathrm{H}_{6} \mathrm{O}: \mathrm{C}, 36.98 ; \mathrm{H}, 5.85 ; \mathrm{N}, 8.62$. Found: C, 36.62; H, 5.99; N, 8.65.

\section{Pressure-Area Isotherms and Langmuir-Blodgett (LB) Film Deposition.}

Pressure-Area isotherms were recorded on a KSV5000 model computer-controlled trough. A solution of complex salt 1 in chloroform $\left(5 \times 10^{-4} \mathrm{M}\right)$ was spread onto an ultrapure water subphase (resistance larger than $18 \mathrm{M} \Omega$ ) obtained from a Milli-Q Millipore apparatus. Films on simple glass slides and precoated ITO slides were obtained by vertical dipping. The substrates were made hydrophilic by being first washed with methanol then boiled in a mixture of aqueous $\mathrm{H}_{2} \mathrm{O}_{2} 30 \%$-aqueous $\mathrm{NH}_{3}$ for 20 minutes and finally rinsed thoroughly with ultrapure water. The Langmuir curve (surface pressure/Area or $\pi / \mathrm{A}$ ) recorded under a constant compression of $5 \mathrm{~mm} \mathrm{~min}^{-1}$ is shown in Figure $\mathrm{S} 1$. The isotherm shows a steep rise in surface pressure with a high collapse pressure of ca. $55 \mathrm{mN} \mathrm{m}^{-1}$. Assuming that layer 
formed is monomolecular, the limiting surface area per molecule obtained from extrapolation of the steepest portion of the curve to $0 \mathrm{mN} \mathrm{m}^{-1}$ pressure, is $12 \AA^{2}$. Considering that the limiting surface area for a linear fatty acid such as arachidic acid is ca. $20 \AA^{2}$, the calculated value for complex 1 indicates that the molecules are aggregated or stacked and the film is clearly not a single molecule thick. The compression experiment was repeated several times leading to the same Langmuir curve whatever the concentration, the volume of solution spread on the surface and the compression rate. It should be noted that the exact structure within the films is not of prime importance in this work, but what is crucial is that the observation of SHG both from a monolayer and from alternating multilayers proves that the films must contain a noncentrosymmetric arrangement of the complex chromophores.

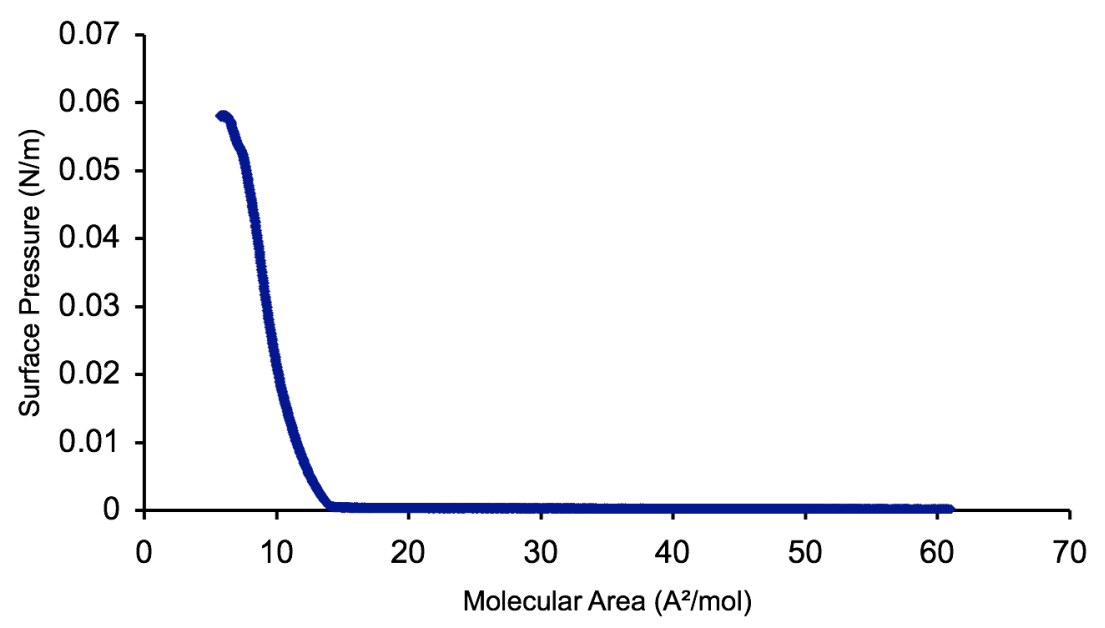

Figure S1. Surface pressure/area ( $\pi / \mathrm{A})$ curve for 1 at $295 \mathrm{~K}$ on a pure water subphase.

Film transfer was investigated by the vertical LB dipping method with hydrophilic glass slides at a constant compression of $20 \mathrm{mN} \mathrm{m}^{-1}$. The efficiency of the transfer process (transfer ratio) is measured by comparing the decrease in the film area on the water/air interface with the area of glass substrate passing through this interface. The transfer ratios measured for successive upstrokes and downstrokes are close to unity $( \pm 10 \%)$, indicating that the transfer process is well-behaved and that the arrangement in the multilayer film is centrosymmetric (Y-type). The absorbance due to the MLCT band at $530 \mathrm{~nm}$ increases linearly with the number of layers (Figure S2), consistent with a homogeneous deposition, and is independent of the film thickness. 


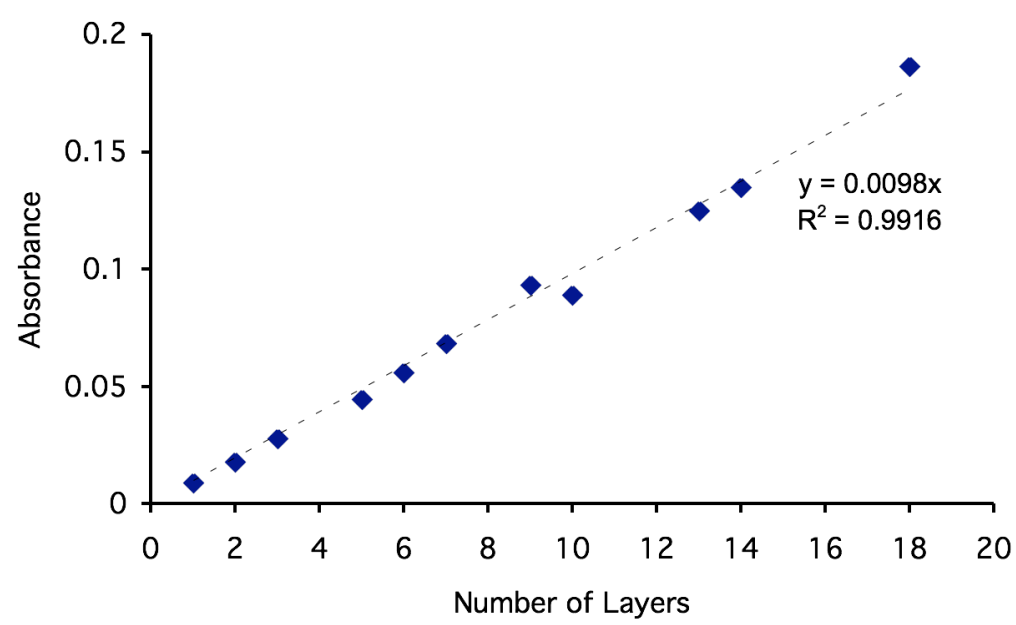

Figure S2. Absorbance at $530 \mathrm{~nm}$ of Y-type LB multilayer films of $\mathbf{1}$ at $295 \mathrm{~K}$.

Second Harmonic Generation (SHG) and Redox-Switching Measurements. All SHG measurements were performed using a Q-switched $\mathrm{Nd}^{3+}$ :YAG laser (model Quanta Ray, Spectra Physics) with $10 \mathrm{~ns}$ pulses, repetition rate of $10 \mathrm{~Hz}$ and an average output power of $100 \mathrm{~mW}$. The sample was irradiated at a $45^{\circ}$ angle of incidence, the input polarisation was chosen to be p-polarised and all the second harmonic light at $532 \mathrm{~nm}$ was detected in transmission. For the electrochemical redox-switching experiment, a three bilayer film (where one bilayer contains a layer of $\mathbf{1}$ and a layer of inactive arachidic acid) was deposited on an ITO-coated glass substrate, serving as a working electrode. This film was placed in a commercially available cuvette (hellma). The sample was oriented at $45^{\circ}$ with respect to the incoming laser beam. A silver wire was used as the reference electrode and a platinum wire serves as a counter electrode. An electrolyte solution of $0.1 \mathrm{M}$ of $\mathrm{NaBF}_{4}$ in water was used. In this modified electrochemical cell a potential of $1 \mathrm{~V}$ was applied for about 2 min to effect oxidation of the film, while a potential of $0 \mathrm{~V}$ was applied to reduce the film to its original state. In all cases, the SHG data were recorded only once the signal had stabilized. The original paper that describes the combination of such an in situ electrochemical approach with hyper-Rayleigh scattering experiments is: Asselberghs, I.; Clays, K.; Persoons, A.; McDonagh, A. M.; Ward, M. D.; McCleverty, J. A. Chem. Phys. Lett. 2003, 368, 408-411.

(1) Coe, B. J.; Harris, J. A.; Harrington, L. J.; Jeffery, J. C.; Rees, L. H.; Houbrechts S.; Persoons, A. Inorg. Chem. 1998, 37, 3391-3399.

(2) Curtis, J. C.; Sullivan, B. P.; Meyer, T. J. Inorg. Chem. 1983, 22, 224-236. 